\title{
Alterations of the expression of T-cell-related costimulatory CD28 and downregulatory CDI52 (CTLA-4) molecules in patients with B-cell chronic lymphocytic leukaemia
}

\author{
I Frydecka*,I,2, A Kosmaczewska', D Bocko', L Ciszak', D Wolowiec ${ }^{2}, K^{\prime}$ Kuliczkowski ${ }^{2}$ and I Kochanowska' \\ 'Institute of Immunology and Experimental Therapy, Polish Academy of Sciences, R Weigla I2, 53-I I 4 Wroclaw, Poland; '² Department of Haematology, \\ Medical University, Pasteura 4, 50-367 Wroclaw, Poland
}

In the present study, we have examined the kinetics and magnitude of expression of the CD28 and CDI52 molecules on unstimulated and anti-CD3 + rlL-2-stimulated peripheral blood CD4 + and CD8 + T cells in patients with chronic lymphocytic leukaemia (B-CLL) and controls. The mean percentages of both CD3 +/CD4 +/CD28 + and CD3 +/CD8 +/CD28+ cells were significantly lower in B-CLL than in controls before culture, decreased rapidly, reaching their lowest levels between 24 and $48 \mathrm{~h}$, and returned to basal levels after $72 \mathrm{~h}$ of culture. In controls, the lowest proportions of CD3 + /CD $4+/ \mathrm{CD} 28+$ and $\mathrm{CD} 3+/ \mathrm{CD} 8+/$ CD28 + cells were found after $24 \mathrm{~h}$ and returned to prestimulation levels after $48 \mathrm{~h}$ of stimulation. We observed significantly higher proportions of unstimulated CD3 + /CD4 + /CDI52 + and CD3 +/CD8 + /CDI52 + cells in B-CLL patients than in controls. The highest percentages of CD3 +/CD4 +/CDI52 + and CD3 +/CD8 +/CDI52 + cells were observed in controls after $72 \mathrm{~h}$, and in B-CLL patients after $24 \mathrm{~h}$, and remained statistically higher after 48, 72 and $96 \mathrm{~h}$ of stimulation. CDI 52 molecule expression returned to prestimulation levels after $96 \mathrm{~h}$ of culture in controls, and after $120 \mathrm{~h}$ in B-CLL patients. The abnormal kinetics and levels of CD28 and CDI52 expression on T cells in B-CLL may lead to a state of hyporesponsiveness or anergy and could be one of the mechanisms of immune deficiency in this disease.

British Journal of Cancer (2004) 90, 2042-2048. doi:I0.1038/sj.bjc.660I833 www.bjcancer.com

Published online 27 April

(c) 2004 Cancer Research UK

Keywords: B-CLL; CDI52 (CTLA-4); CD28; stimulation

B-cell chronic lymphocytic leukaemia (B-CLL) is the most frequent form of adult leukaemia in the Western world, where it accounts for about $25 \%$ of all leukaemias. In addition to the accumulation and clonal expansion of malignant $\mathrm{B}$ cells, several abnormalities have been demonstrated within the non-malignant T-cell population. The nature and the level of T-cell immune deficiency in BCLL are the object of intense investigations. Recently, there has been a growing appreciation of the importance of the costimulatory and inhibitory regulation pathways in normal and diseaserelated cellular immune function.

The effective activation of naive $\mathrm{T}$ lymphocytes requires the generation of a specialised contact area between the $\mathrm{T}$ cell and the antigen-presenting cells (APCs) known as the immunologic synapse (Dustin and Cooper, 2000). This area of interaction is generated by the aggregation of different specialised receptors and signalling molecules, called supramolecular activation clusters. The differentiation and expansion of a $\mathrm{T}$ cell depends upon two signals: an antigen-specific interaction between the $\mathrm{T}$-cell receptor (TCR) and the specific peptide embedded in major histocompatibility complex (MHC) molecules displayed on the surface of the APC, and an antigen-nonspecific interaction between a costimu-

*Correspondence: Professor I Frydecka;

E-mail: frydecka@hemat.am.wroc.pl

Received 30 May 2003; revised 8 March 2004; accepted 9 March 2004; published online 27 April latory receptor and its ligand. $\mathrm{CD} 28$ is the primary T-cell costimulatory molecule, which is expressed constitutively on almost all CD4 $+\mathrm{T}$ cells and on about $50 \%$ of $\mathrm{CD} 8+\mathrm{T}$ cells. Upon interaction with the ligands B.7-1 (CD80) and/or B.7-2 (CD86), CD28 transduces a signal that enhances T-cell proliferation and cytokine secretion and sustains T-cell response (reviewed in Bocko et al, 2002). In the absence of an appropriate costimulation, TCR occupancy alone can lead to T-cell unresponsiveness or clonal anergy, in which $\mathrm{T}$ cells are unable to proliferate or secrete cytokines in response to a secondary stimulation (Schwartz, 1996). Consistent with this, CD28-negative transgenic mice exhibit profound defects in mitogenic responses (Shahinian et al, 1993), and germinal centres are not formed in response to immunisation (Ferguson et al, 1996).

Conversely, the CD28 homologue CD152 (CTLA-4: cytotoxic Tlymphocyte-associated antigen-4), which is transiently expressed on activated $\mathrm{T}$ cells, reaching its highest level after $48-72 \mathrm{~h}$ of stimulation (Walunas et al, 1994; Kosmaczewska et al, 2002), plays an inhibitory role in regulating $\mathrm{T}$-cell activation. The expression of CD152 within T-cell population is restricted to the subset of T cells that also express CD28 on the cell surface (Lindsten et al, 1993). CD152 binds the same ligands like CD28, but has an affinity 1050-fold higher than the CD28 receptor for B.7-1 (CD80) and B.7-2 (CD86) molecules (Linsley et al, 1994). CD152 mRNA and protein synthesis is induced by the ligation of CD28 with its ligands (Lindsten et al, 1993). CD152 engagement inhibits the induction of 
the IL-2 receptor alpha chain (CD25), CD69 molecule expression, CD3/CD28-induced IL-2 mRNA accumulation, and secretion of IL2 (Krummel and Allison, 1996; Blair et al, 1998). CD152 ligation also augments the production of transforming growth factor beta (TGF-beta) (Chen et al, 1998). Mice lacking CD152 as a result of targeted gene disruption develop a fatal spontaneous lymphoproliferative disease with massive lymphocyte infiltrates in many organs (Waterhouse et al, 1995; Tivol et al, 1997).

The outcome of an immune response involves a balance between CD28-mediated T-cell activation and CD152-mediated inhibition. Little is known about CD28 and CD152 expression on peripheral blood (PB) $\mathrm{T}$ cells in patients with B-CLL. To the best of our knowledge, only three papers have been published on the expression of these molecules in B-CLL patients so far (Rossi et al, 1996; Van den Hove et al, 1998; Scrivener et al, 2001). Our study was designed to evaluate the kinetics and expression of CD28 and $\mathrm{CD} 152$ on unstimulated and anti-CD3 + rIL-2-stimulated $\mathrm{CD} 4+$ and CD8 + T lymphocytes from B-CLL patients.

\section{MATERIALS AND METHODS}

\section{Patients}

Samples from 33 untreated patients aged 33-80 years (mean: 64 . $6 \pm 10.5$ years) fulfilling the morphologic and immunophenotypic criteria for the diagnosis of B-CLL were studied. Patients were graded according to Rai's staging system as at stages III (17 cases) and IV (16 cases). The control samples consisted of PB from 25 age- and sex-matched healthy individuals.

The study was approved by the local research ethics committee.

\section{Isolation of peripheral blood mononuclear cells and culture conditions}

Peripheral blood mononuclear cells (PBMCs) were separated from freshly drawn heparinised peripheral venous blood of the B-CLL patients and healthy donors by buoyant density gradient centrifugation on Lymphoflot (Biotest AG, Germany) and washed three times in $0.9 \%$ saline. Peripheral blood mononuclear cells were suspended at $1 \times 10^{6} \mathrm{PBMCs} \mathrm{ml}^{-1}$ in RPMI 1640 medium (Gibko, Paisley, UK) supplemented with $10 \%$ foetal calf serum (Flow Labs, UK), L-glutamine and $50 \mu \mathrm{g} \mathrm{ml}^{-1}$ gentamycin (Gibko), and cultured with $5 \mathrm{ng} \mathrm{ml}^{-1}$ of anti-CD3 monoclonal antibodies (MoAbs) (Ortho, Neckargemund, Germany) and $500 \mathrm{U} \mathrm{ml}^{-1}$ of rIL2 (Eurocetus, Amsterdam, The Netherlands). In our model, rIL-2 served as a second signal to induce optimal immune response. Control cultures without stimulants were included in each experiment. The cultures were incubated at $37^{\circ} \mathrm{C}$ in a humidified atmosphere containing $5 \% \mathrm{CO}_{2}$ for $24,48,72,96$ and $120 \mathrm{~h}$.

\section{Flow cytometric analysis}

All experiments on the fresh and cultured cells were carried out by triple labelling with anti-CD152 (CTLA-4)/RPE (PharMingen, Becton Dickinson Company, San Diego, CA, USA), anti-CD3/ PerCP (Becton Dickinson, San Jose, CA, USA), anti-CD4/FITC (Becton Dickinson, San Jose, CA, USA), anti-CD8/FITC (Becton Dickinson, San Jose, CA, USA), anti-CD28/FITC (Serotec, UK), anti-CD4/RPE (Becton Dickinson, San Jose, CA, USA) and antiCD8/RPE (Becton Dickinson, San Jose, CA, USA) MoAbs.

Briefly, the cells were incubated for $30 \mathrm{~min}$ at $4{ }^{\circ} \mathrm{C}$ with the antibodies described above, and excess, unbound antibodies were removed by two washes with PBS containing 0.5\% Tween-20. Following these washes, the cells were fixed with PBS (without $\mathrm{Ca}^{2+}$ and $\mathrm{Mg}^{2+}$ ) and analysed by flow cytometry using a FACScalibur flow cytometer (Becton Dickinson, Mountain View, CA, USA). Negative controls were always done by omitting the MoAb as well as by incubating cells with mouse Ig of the same isotype as the MoAbs conjugated with fluoresceine or phycoerythrin.

The results were expressed as the proportions of CD3 $+/ C D 4+$ and CD $3+/ C D 8+$ cells coexpressing CD28 or CD152 antigen. At

Table I The mean percentage of PB CD3+/CD4+/CD28+ and CD3+/CD8+/CD28+ cells before and after 24, 48, 72 and 96 h of anti-CD3+rlL-2 stimulation in patients with B-CLL and healthy controls

\begin{tabular}{|c|c|c|c|c|c|c|}
\hline & \multicolumn{5}{|c|}{ Time (h) } & \multirow[b]{2}{*}{$P$} \\
\hline & 0 & 24 & 48 & 72 & 96 & \\
\hline B-CLL patients $(n=33)$ & $\underset{\text { (I) }}{41.5 \pm 17.1 \%}$ & $\begin{array}{c}20.1 \pm 9.2 \% \\
\text { (III) }\end{array}$ & $\begin{array}{c}22.1 \pm 9.9 \% \\
(V)\end{array}$ & $\begin{array}{c}35.7 \pm 13.5 \% \\
(\mathrm{VII})\end{array}$ & $\underset{(I X)}{36.2 \pm 12.6 \%}$ & $\begin{array}{l}I: I I=0.00 I \\
I: V=0.005 \\
I I I: V=N S \\
V: V I I=0.00 I\end{array}$ \\
\hline Healthy controls $(n=25)$ & $\begin{array}{c}78.9 \pm 7.6 \% \\
(I I)\end{array}$ & $\begin{array}{c}57.0 \pm 8.5 \% \\
(\mathrm{IV})\end{array}$ & $\begin{array}{c}74.7 \pm 6.5 \% \\
(\mathrm{VI})\end{array}$ & $\begin{array}{c}82.2 \pm 6.0 \% \\
(\mathrm{VIII})\end{array}$ & $\begin{array}{c}82.1 \pm 6.4 \% \\
(X)\end{array}$ & $\begin{array}{l}\|: I V=0.002 \\
I V: V I=0.004 \\
\|: V I=N S \\
V I: V I I I=N S\end{array}$ \\
\hline$P$ & $\mid: \|=0.0002$ & $I I I: I V=0.000 I$ & $V: V I=0.000 I$ & $\mathrm{VII}: \mathrm{VIII}=0.000 \mathrm{I}$ & $|X: X=0.000|$ & \\
\hline \multicolumn{7}{|l|}{$\mathrm{CD} 3+/ \mathrm{CD} 8+/ \mathrm{CD} 28+$} \\
\hline Healthy controls $(n=25)$ & $\begin{array}{c}59.3 \pm 9.8 \% \\
\text { (II) }\end{array}$ & $\begin{array}{c}42.6 \pm 11.2 \% \\
(\mathrm{IV})\end{array}$ & $\begin{array}{c}52.5 \pm 8.3 \% \\
(\mathrm{VI})\end{array}$ & $\begin{array}{c}54.7 \pm 8.3 \% \\
(\mathrm{VIIII})\end{array}$ & $\underset{(X)}{55.0 \pm 7.6 \%}$ & $\begin{array}{l}\|: I V=0.04 \\
I V: V I=0.05 \\
\|: V I=N S \\
V I: V I I I=N S\end{array}$ \\
\hline$P$ & $\mathrm{I}: \|=0.005$ & $I I I: I V=0.00 \mid$ & $V: V I=0.00 I$ & $V \mid I: V I I I=0.01$ & $\mid X: X=0.01$ & \\
\hline
\end{tabular}


least 10000 events per sample were analysed in triple staining analysis. The CellQuest program was used for statistical analysis of the acquired data.
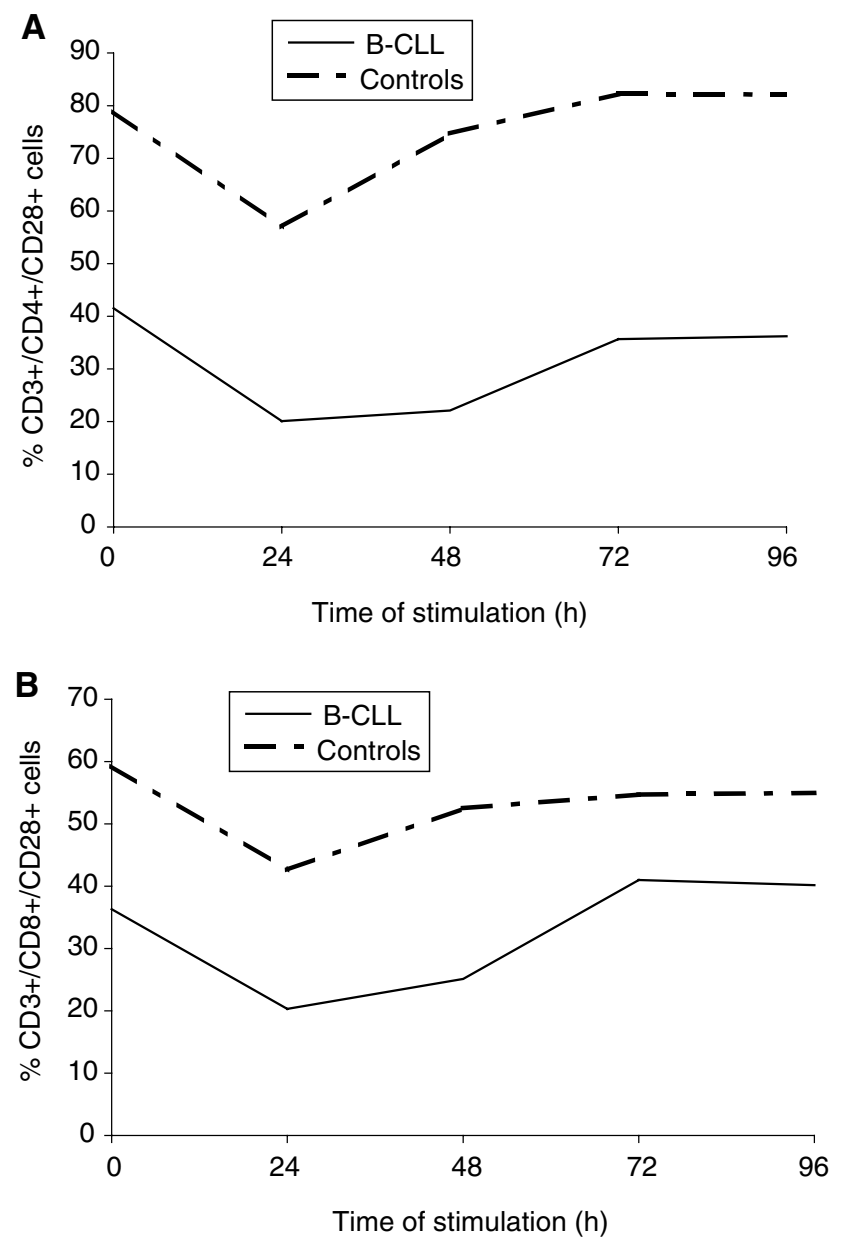

Figure I The mean percentage of PB CD3 +/CD4 +/CD28+ cells (A) and CD3 + /CD8 + /CD28 + cells (B) before and after ex vivo 24, 48, 72 and $96 \mathrm{~h}$ of anti-CD3 + rlL-2 stimulation in patients with B-CLL and normal subjects.

\section{Statistical analysis}

Statistical analysis was performed using Mann-Whitney $U$-test and ANOVA test for repeated measurements. Differences were considered as statistically significant when the $P$-value was $\leqslant 0.05$. Summary statistics are given as the mean \pm s.d.

\section{RESULTS}

The level and kinetics pattern of CD28 expression on CD3 $+/$ CD4 + and CD3 $+/$ CD8 $+\mathrm{T}$ cells in B-CLL patients and controls

The mean percentage of CD3 + /CD4 + cells coexpressing CD28 was significantly lower in the B-CLL patients than in the controls before stimulation $(P=0.0002)$ and after $24 \mathrm{~h}(P=0.0001), 48 \mathrm{~h}$ $(P=0.0001), 72 \mathrm{~h}(P=0.0001)$ and $96 \mathrm{~h}(P=0.0001)$ of ex vivo stimulation (Table 1 ). The mean percentage of CD3 $+/$ CD $8+I$ $\mathrm{CD} 28+$ cells was also significantly lower in B-CLL patients than in controls before stimulation $(P=0.005)$, and after $24 \mathrm{~h}(P=0.001)$, $48 \mathrm{~h}(P=0.001), 72 \mathrm{~h}(P=0.01)$ and $96 \mathrm{~h}(P=0.01)$ of stimulation (Table 1). The lowest proportions of $\mathrm{CD} 3+/ \mathrm{CD} 4+/ \mathrm{CD} 28+$ and $\mathrm{CD} 3+/ \mathrm{CD} 8+/ \mathrm{CD} 28+$ cells in B-CLL patients were observed between 24 and $48 \mathrm{~h}$ of stimulation, and returned to basal levels after $72 \mathrm{~h}$ of culture. In healthy subjects, the lowest proportions of $\mathrm{CD} 3+/ \mathrm{CD} 4+/ \mathrm{CD} 28+$ and $\mathrm{CD} 3+/ \mathrm{CD} 8+/ \mathrm{CD} 28+$ cells were observed after $24 \mathrm{~h}$ and returned to prestimulation levels after $48 \mathrm{~h}$ (Figure 1).

The mean fluorescence intensity (MFI) of the CD28 + cells, as a measure of the antigen density on the cell surface, was significantly lower on CD4 $+\mathrm{T}$ cells in B-CLL patients compared with controls after $48 \mathrm{~h} \quad(P=0.01)$ and $72 \mathrm{~h} \quad(P=0.03) \quad$ (Table 2), while significantly lower MFI values of CD28 on CD3 + /CD8 + cells compared with controls were found only after $72 \mathrm{~h}$ of stimulation $(P=0.03)$ (Table 2).

The level and kinetics pattern of CD152 expression on CD3 $+/$ CD4 + and CD3 + /CD8 + T cells in B-CLL patients and controls

The frequency of $\mathrm{CD} 3+/ \mathrm{CD} 4+/ \mathrm{CD} 152+$ cells was significantly higher in B-CLL patients than controls on freshly drawn PB cells $(P=0.001)$ and after $24 \mathrm{~h}(P=0.0001), 48 \mathrm{~h}(P=0.0001), 72 \mathrm{~h}$ $(P=0.0005), 96 \mathrm{~h}(P=0.001)$ and $120 \mathrm{~h}(P=0.001)$ of stimulation (Table 3).

The mean percentage of CD3 + /CD $8+/ \mathrm{CD} 152+$ cells was also markedly elevated in B-CLL compared with controls before stimulation $(P=0.0001)$ and after $24 \mathrm{~h} \quad(P=0.0005), \quad 48 \mathrm{~h}$ $(P=0.0003), \quad 72 \mathrm{~h} \quad(P=0.02), \quad 96 \mathrm{~h} \quad(P=0.0001) \quad$ and $\quad 120 \mathrm{~h}$ $(P=0.0001)$ of stimulation (Table 3$)$.

Table 2 MFI values of CD28 on PB CD3+/CD4+ cells and CD3+/CD8+ cells, expressed in arbitrary units (AU), before and after 24, 48, 72 and 96 h of anti-CD3+rlL-2 stimulation in patients with B-CLL and healthy controls

\begin{tabular}{|c|c|c|c|c|c|}
\hline & \multicolumn{5}{|c|}{ MFI of CD28 } \\
\hline & $\mathbf{O h}$ & $24 \mathrm{~h}$ & $48 \mathrm{~h}$ & $72 \mathrm{~h}$ & $96 \mathrm{~h}$ \\
\hline \multicolumn{6}{|l|}{$\mathrm{CD} 3+/ C D 4+$} \\
\hline B-CLL patients $(n=33)$ & $41.0 \pm 29.4$ & $39.4 \pm 14.7$ & $47.4 \pm 30.0$ & $36.8 \pm 29.8$ & $49.4 \pm 33.8$ \\
\hline Healthy controls $(n=25)$ & $38.2 \pm 11.8$ & $47.5 \pm 4.6$ & $65.0 \pm 17.8$ & $65.3 \pm 11.8$ & $55.2 \pm 13.5$ \\
\hline$P$ & $\overline{N S}$ & $\overline{N S}$ & $0 . \overline{0} 1$ & $0 . \overline{0} 3$ & $\overline{N S}$ \\
\hline \multicolumn{6}{|l|}{$\mathrm{CD} 3+/ \mathrm{CD} 8+$} \\
\hline B-CLL patients $(n=33)$ & $44.7 \pm 21.1$ & $45.3 \pm 18.5$ & $52.0 \pm 25.0$ & $42.1 \pm 31.7$ & $48.7 \pm 32.6$ \\
\hline Healthy controls $(n=25)$ & $40.8 \pm 31.3$ & $53.3 \pm 28.4$ & $75.5 \pm 41.1$ & $69.9 \pm 33.1$ & $59.8 \pm 37.6$ \\
\hline$P$ & NS & NS & NS & 0.03 & NS \\
\hline
\end{tabular}


Table 3 The mean percentage of PB CD3+/CD4+/CDI52+ cells and CD3+/CD8+/CDI52+ cells before and after 24, 48, 72, 96 and I20 h of antiCD3+rlL-2 stimulation in patients with B-CLL and healthy controls

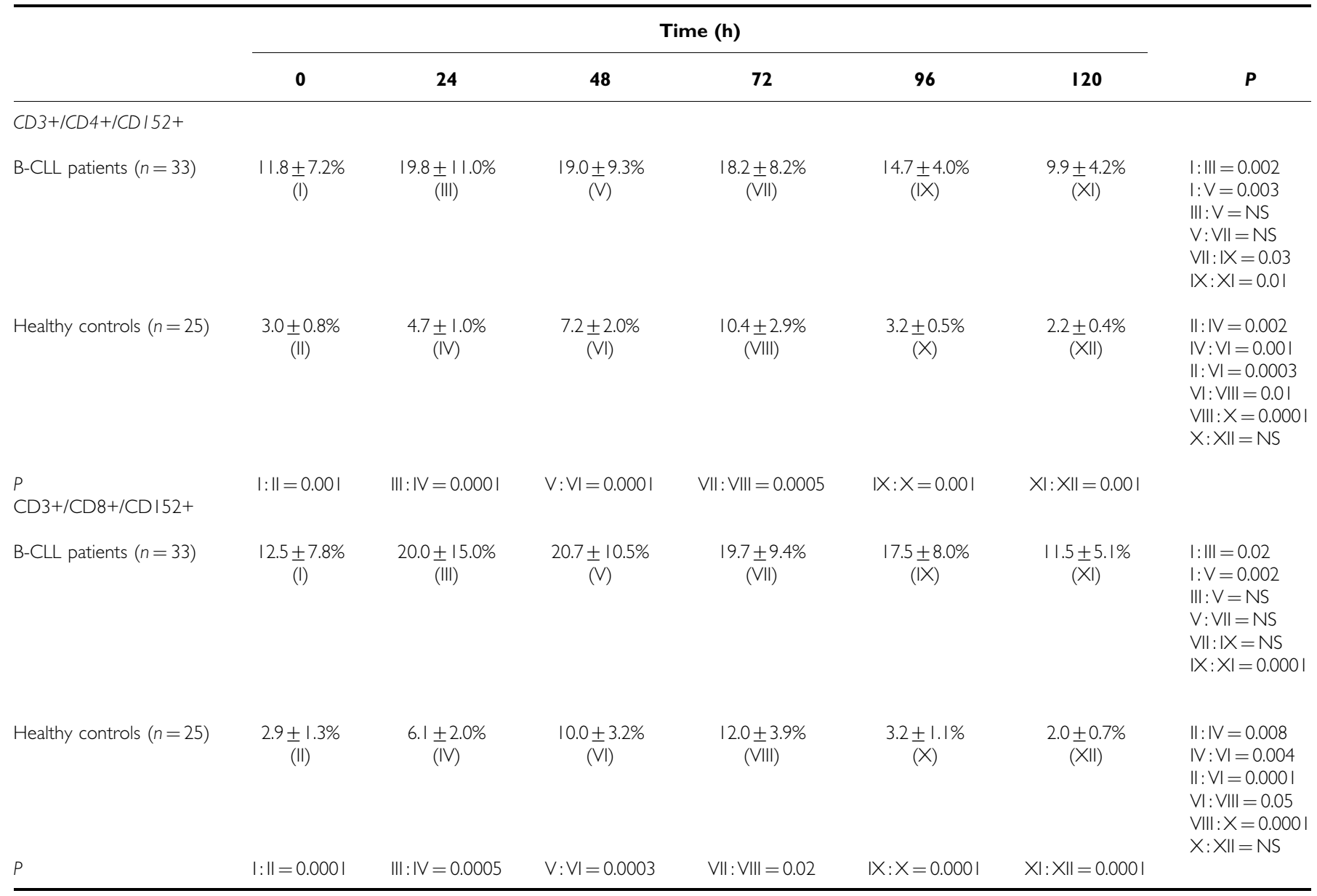

In healthy subjects, the proportions of both $\mathrm{CD} 3+/ \mathrm{CD} 4+$ I $\mathrm{CD} 152+$ and $\mathrm{CD} 3+/ \mathrm{CD} 8+/ \mathrm{CD} 152+$ cells increased gradually, peaked after $72 \mathrm{~h}$ after stimulation, and returned to basal levels after $96 \mathrm{~h}$ of stimulation. In contrast, in B-CLL patients, the highest proportion of triple-positive cells was observed after $24 \mathrm{~h}$ of stimulation, slowly decreased on subsequent days of stimulation, and returned to prestimulation levels after $120 \mathrm{~h}$ of culture (Figure 2).

In addition to the increased frequency of $\mathrm{CD} 3+/ \mathrm{CD} 4+1$ $\mathrm{CD} 152+$ cells, we also observed significantly higher MFI values of $\mathrm{CD} 152$ on $\mathrm{CD} 3+/ \mathrm{CD} 4+$ in B-CLL patients compared with controls on unstimulated $(P=0.001)$ as well as on stimulated cells after 24,48 , and $72 \mathrm{~h}$ of culture $(P=0.04,0.01$ and 0.03 , respectively) (Table 4). Similar results were obtained in the $\mathrm{CD} 3+/ \mathrm{CD} 8+$ subpopulation on unstimulated $(P=0.01)$ and stimulated cells $24 \mathrm{~h} \quad(P=0.05), 48 \mathrm{~h} \quad(P=0.01)$ and $72 \mathrm{~h}$ $(P=0.05)$ after stimulation (Table 4$)$.

\section{Comparison between CD28 as well as CD152 expressions on CD4 + and CD8 $+\mathrm{T}$ cells before and after ex vivo stimulation in healthy donors and B-CLL patients}

In the control group, a significantly higher proportion of $\mathrm{CD} 3+1$ $\mathrm{CD} 4+/ \mathrm{CD} 28+$ than $\mathrm{CD} 3+/ \mathrm{CD} 8+/ \mathrm{CD} 28+$ cells was found before and after $24,48,72$ and $96 \mathrm{~h}$ of stimulation $(P=0.0005$, $0.0005,0.0008,0.0001$ and 0.0001 , respectively). Mean fluorescence intensity values did not differ between the subsets of lymphocytes studied.
In the case of CD152 molecule expression, markedly higher proportions of $\mathrm{CD} 3+/ \mathrm{CD} 8+/ \mathrm{CD} 152+$ than $\mathrm{CD} 3+/ \mathrm{CD} 4+/$ CD152 + cells after 24 and $48 \mathrm{~h}$ of stimulation $(P=0.05$ and 0.04 , respectively) as well as higher MFI values tested at the same time points ( $P=0.01$ and 0.04 , respectively) were found.

In contrast, in B-CLL patients, there were similar frequencies of $\mathrm{CD} 3+/ \mathrm{CD} 4+/ \mathrm{CD} 28+$ and $\mathrm{CD} 3+/ \mathrm{CD} 8+/ \mathrm{CD} 28+$ cells $($ Table 1$)$ as well as $\mathrm{CD} 3+/ \mathrm{CD} 4+/ \mathrm{CD} 152+$ and $\mathrm{CD} 3+/ \mathrm{CD} 8+/ \mathrm{CD} 152+$ cells (Table 3). Similarly, there were no marked differences between the MFI values of both the CD28 + cells and CD152+ cells within the subsets of $\mathrm{T}$ cells studied in these patients.

\section{DISCUSSION}

There are only a few reports regarding CD28 expression on unstimulated and stimulated T lymphocytes in B-CLL. However, no data concerning the kinetics pattern of the studied molecules on the subsets of T cells in B-CLL patients and controls have been reported so far. Rossi et al (1996) found a significant decrease in CD28 molecules on $\mathrm{T}$ cells in 33 patients with B-CLL. Similar results were obtained by Van den Hove et al (1998) in 12 B-CLL patients. In a recent study, Scrivener et al (2001) reported a decreased proportion of CD2 +/CD28 + cells, which did not change upon $4 \mathrm{~h}$ of stimulation with OKT3 MoAb in 27 patients with B-CLL. The same authors also found a complete lack of CD152 expression on freshly drawn PB T-cells of half of the patients. The $48 \mathrm{~h}$ ex vivo stimulation with OKT3 MoAb or PHA 
increased the mean proportion of $\mathrm{CD} 2+/ \mathrm{CD} 152+$ from $1.9 \pm 2.7$ to $6.8 \pm 5.1 \%$. In the present study, we demonstrated for the first time abnormal levels and a different kinetics pattern of costimulatory CD28 and inhibitory CD152 molecules expression
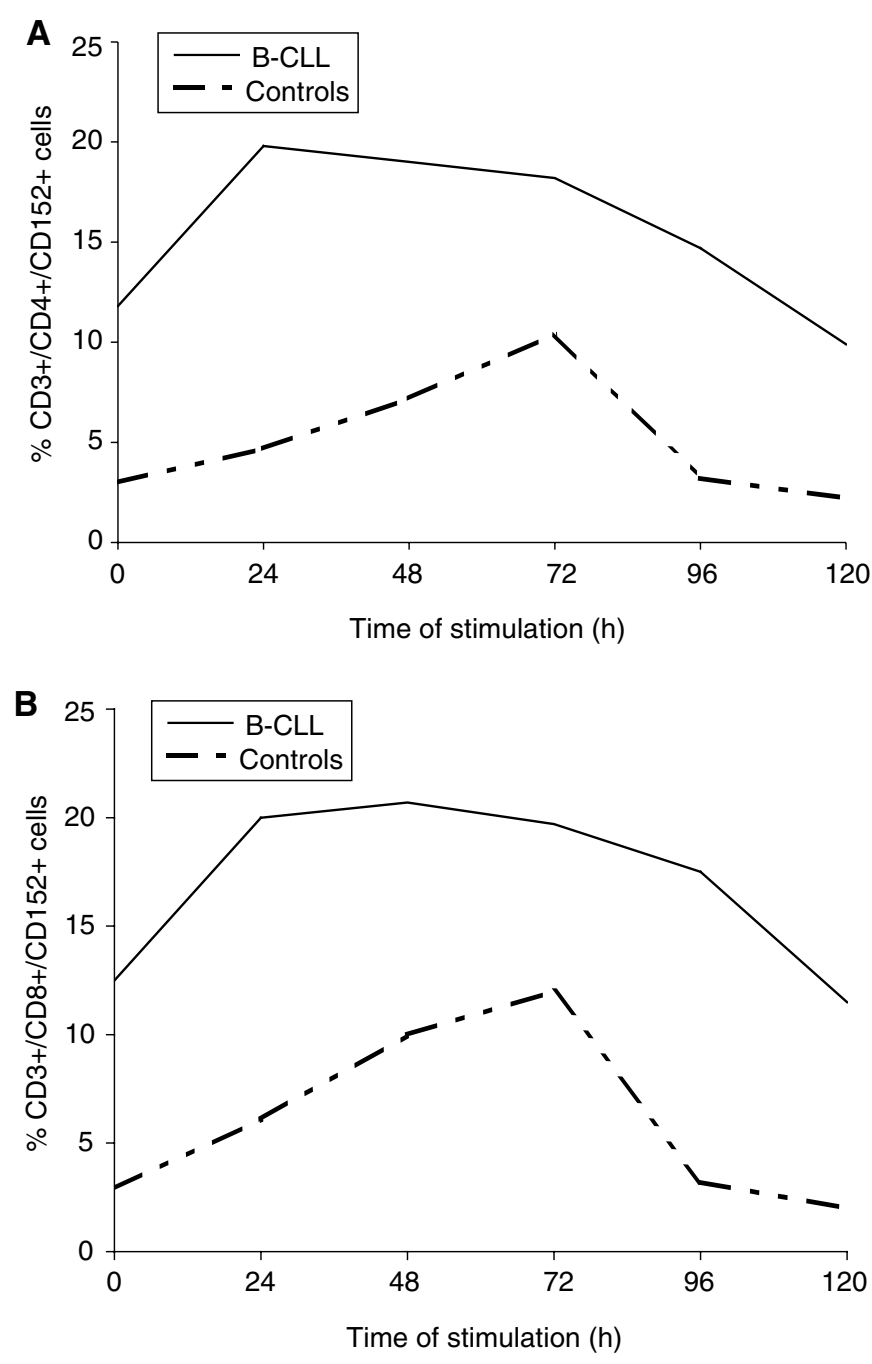

Figure 2 The mean percentage of PB CD3 $+/ C D 4+/ C D 152+$ cells (A) and CD3 + /CD8 + /CDI52 + cells (B) before and after ex vivo 24, $48,72,96$ and $120 \mathrm{~h}$ of anti-CD3 + rlL-2 stimulation in patients with B$120 \mathrm{~h}$ of anti-CD3+rlL-2 stimulation in patients with B-CLL and healthy controls on ex vivo-stimulated $\mathrm{CD} 3+/ \mathrm{CD} 4+$ and $\mathrm{CD} 3+/ \mathrm{CD} 8+\mathrm{PB} \mathrm{T}$ cells in B-CLL patients compared with healthy controls.

Since an analysis of CD28-positive cells within the CD8 population would be complicated by the fact that the CD8 subset is comprised of both CD3 + T lymphocytes and CD3- NK cells (Perussia et al, 1983), we performed our studies on CD4 + and $\mathrm{CD} 8+\mathrm{T}$ cells using a triple immunostaining method (a T-cell marker, T-cell-subset markers, and CD28 or CD152). In B-CLL patients, the proportions of $\mathrm{CD} 28+$ cells within the $\mathrm{CD} 3+1$ $\mathrm{CD} 4+$ and $\mathrm{CD} 3+/ \mathrm{CD} 8+$ populations before and during stimulation were significantly lower at each time point tested, and more pronounced in CD4 $+\mathrm{T}$ cells compared with controls. After stimulation in the control subjects, we found, similar to other reports (Linsley et al, 1993), a transient decrease of CD28 expression on both subsets of $\mathrm{T}$ cells after $24 \mathrm{~h}$, which returned to the prestimulation level after $48 \mathrm{~h}$. In the B-CLL patients, the lowest proportions of both subsets of CD28-positive $\mathrm{T}$ cells were observed between 24 and $48 \mathrm{~h}$ and returned to basal levels after $72 \mathrm{~h}$ of ex vivo stimulation. In addition to the decreased frequency of $\mathrm{CD} 3+/ \mathrm{CD} 4+/ \mathrm{CD} 28+$ and $\mathrm{CD} 3+/ \mathrm{CD} 8+/ \mathrm{CD} 28+$ cells in $\mathrm{B}-$ CLL patients, the MFI of the CD28 + cells, as a measure of the antigen density on the cell surface, was also lower in patients at 48 and $72 \mathrm{~h}$ on $\mathrm{CD} 4+\mathrm{T}$ cells and $72 \mathrm{~h}$ on $\mathrm{CD} 8+\mathrm{T}$ cells after stimulation than in the controls.

The mechanisms underlying the abnormalities in CD28 expression in B-CLL patients are not fully understood. The CD28 molecule is lost by normal lymphocytes after repeated stimulation with IL-2 in long-term culture (Labalette et al, 1999). Based on the fact that $\mathrm{T}$ lymphocytes from $\mathrm{B}-\mathrm{CLL}$ patients have a phenotype of activated cells, that is, HLA-DR,$+ \mathrm{CD} 38+, \mathrm{CD} 45 \mathrm{RO}+, \mathrm{CD} 11 \mathrm{c}+$, CD69 +, CD71 +, CD40L + (Dianzani et al, 1994; Van den Hove et al, 1998; Scrivener et al, 2001), it can be suggested that the loss of CD28 molecule on T lymphocytes before culture is related to a prolonged in vivo activation of these cells. Our finding of a markedly increased expression of the inducible suppressory CD152 molecule on freshly drawn CD4 + and CD8 $+\mathrm{T}$ cells in $\mathrm{B}-\mathrm{CLL}$ patients strengthens the suggestion that $\mathrm{T}$ cells in B-CLL are in a partial state of activation. The loss of CD28 expression on BCLL T cells may be also related to the influence of the elevated TNF-alpha serum levels produced by neoplastic B lymphocytes and T cells in patients with B-CLL (Adami et al, 1994; BojarskaJunak et al, 2002; Gallego et al, 2003). It has been shown that exposure of T cells to TNF-alpha leads to the direct repression of the transcriptional activity of the CD28 gene promoter (Bryl et al, 2001).

The mechanisms leading to the prolonged downregulation of CD28 expression after ex vivo stimulation in B-CLL patients is difficult to explain. The changes in CD28 expression kinetics due to differential dynamics of proliferation of CD28-negative T cells seem unlikely, since these cells display a poor proliferative

Table $4 \mathrm{MFI}$ values of CDI52 on PB CD3+/CD4+ cells and CD3+/CD8+ cells, expressed in arbitrary units (AU), before and after 24, 48, 72, 96 and

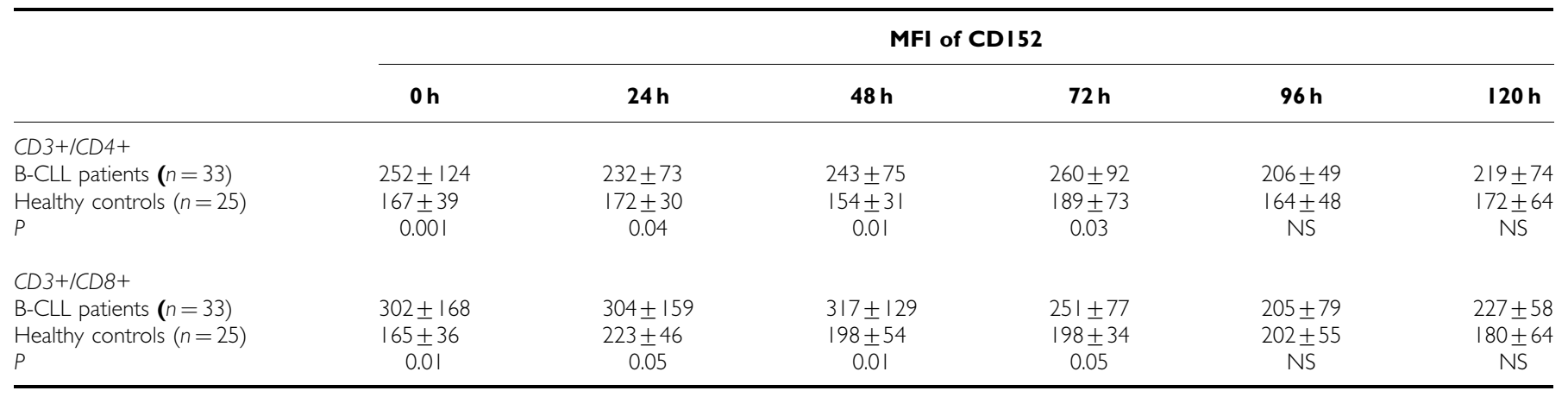


capacity, which cannot be overcome by the addition of exogenous IL-2 (Azuma et al, 1993). The fact that the reversion of CD28 took place rapidly (between 24 and $48 \mathrm{~h}$ of stimulation) favours the interpretation that in B-CLL patients the prolonged downregulation of the surface CD28 molecule may result from enhanced ligation-stimulated $\mathrm{CD} 28$ receptor endocytosis, and/or disturbed recycling to the cell surface or increased proteolytic intracellular degradation.

The expression and kinetics pattern of the CD152 molecule on $\mathrm{PB} \mathrm{CD} 4+$ and $\mathrm{CD} 8+\mathrm{T}$ cells after stimulation also differed markedly from that observed in normal subjects. The frequencies of $\mathrm{CD} 3+/ \mathrm{CD} 4+/ \mathrm{CD} 152+$ and $\mathrm{CD} 3+/ \mathrm{CD} 8+/ \mathrm{CD} 152+$ cells were significantly higher at each time point tested compared with normal subjects. After stimulation in normal subjects, the highest proportions of $\mathrm{T}$ cells coexpressing CD152 molecule were found after $72 \mathrm{~h}$ of culture, which is similar to the findings of others (Walunas et al, 1996) and our own previous report (Kosmaczewska et al, 2002). In patients with B-CLL, the highest proportions of $\mathrm{CD} 4+\mathrm{T}$ cells and CD8 $+\mathrm{T}$ cells coexpressing CD152 were observed after $24 \mathrm{~h}$ and returned to basal levels after $120 \mathrm{~h}$, but after $96 \mathrm{~h}$ in controls. The results of our present study showing the abnormal kinetics and expression of CD28 on T cells in B-CLL may provide a possible explanation for the observed alterations in CD152 expression after ex vivo stimulation. It has been established that the physiological downregulation of CD28 expression at both the mRNA and protein levels during the first $24 \mathrm{~h}$ of stimulation rapidly and strongly enhances transcription of the CTLA-4 gene (Lindsten et al, 1993; Linsley et al, 1993). We suggest that the significantly lower CD28 antigen expression on both subsets of unstimulated $\mathrm{T}$ cells and its more profound and long-lasting downregulation after stimulation compared with normal controls

\section{REFERENCES}

Adami F, Guarini A, Pini M, Sancetta R, Masaia M, Trentin L, Foa R, Semenzato G (1994) Serum levels of tumor necrosis factor- $\alpha$ in patients with B-cell chromic lymphocytic leukaemia. Eur J Cancer 30A: 12591263

Azuma M, Philips JH, Lanier LL (1993) CD28 - T lymphocytes. Antigenic and functional properties. J Immunol 150: 1147-1159

Bartik MM, Welker D, Kay NE (1998) Impairment in immune cell function in B cell chronic lymphocytic leukemia. Sem in Oncol 25: 27-33

Blair PJ, Riley JL, Levine BL, Lee KP, Craighead N, Francomano T, Perfetto SJ, Gray GS, Carreno BM, June CH (1998) CTLA-4 ligation delivers a unique signal to resting human $\mathrm{CD} 4 \mathrm{~T}$ cells that inhibits interleukin-2 secretion but allows $\mathrm{Bcl}-\mathrm{X}(\mathrm{L})$ induction. J Immunol 160: $12-15$

Bocko D, Kosmaczewska A, Ciszak L, Teodorowska T, Frydecka I (2002) CD28 costimulatory molecule-expression, structure and function. Arch Immunol Ther Exp 50: 169 - 177

Bojarska-Junak A, Rolinski J, Wasik-Szczepaneko E, Kaluzny Z, Dmoszynska A (2002) Intracellular tumor necrosis factor production by T- and B-cells in B-cell chronic lymphocytic leukemia. Haematologica 87: $490-499$

Bryl E, Vallejo AN, Weyand CM, Goronzy JJ (2001) Down-regulation of CD28 expression by TNF-alpha. J Immunol 167: $3231-3238$

Carreno BM, Bennett F, Chau TA, Ling V, Luxenberg D, Jussif J, Baroja ML, Madrenas J (2000) CTLA-4 (CD152) can inhibit T cell activation by two different mechanisms depending on its level of cell surface expression. $J$ Immunol 165: $1352-1356$

Chen W, Jin W, Wahl SM (1998) Engagement of cytotoxic T lymphocyteassociated antigen 4 (CTLA-4) induces transforming growth factor beta (TGF-beta) production by murine CD4+ T cells. J Exp Med 188: $1849-1857$

Dianzani U, Omede P, Marmont F, DiFranco D, Fusaro A, Bragardo M, Redoglia V, Giaretta F, Mairone L, Boccadoro M, Resegotti L, Pileri A (1994) Expansion of T cells expressing low CD4 or CD8 levels in B-cell chronic lymphocytic leukemia: correlation with disease status and neoplastic phenotype. Blood 83: 2198-2205 as observed in our study may deliver a stronger and prolonged stimulus for $\mathrm{CD} 152$ induction and expression on the $\mathrm{CD} 3+1$ $\mathrm{CD} 4+$ and $\mathrm{CD} 3+/ \mathrm{CD} 8+\mathrm{T}$-cell subpopulations in B-CLL. Since CD152 inhibits $\mathrm{T}$-cell responses, increased expression of CD152 molecule on both subsets of $T$ cells may result in an impairment of T-cell function in patients with B-CLL (Bartik et al, 1998; Lee et al, 1998; Metzler et al, 1999; Carreno et al, 2000; Frydecka et al, 2003; Wolowiec et al, 2003). This hypothesis was confirmed by our previously reported results, which showed strong negative correlations between the proportion of PB CD3 +1 $\mathrm{CD} 152+$ cells and proliferative activity, IL- 2 and IFN- $\gamma$ production in patients with Hodgkin's disease and healthy subjects (Kosmaczewska et al, 2002).

In summary, the dysregulated expression and kinetics of the costimulatory CD28 and downregulatory CD152 molecules on PB T cells of patients with B-CLL may likely have a considerable impact on the biology of T-cell responses and could be one of the mechanisms of immune deficiency in this disease (Bartik et al, 1998). Therapeutic manipulations of the B-7:CD28:CD152 costimulatory and inhibitory pathways may provide a potential avenue for increasing $\mathrm{T}$-cell responses in B-CLL patients.

\section{ACKNOWLEDGEMENTS}

We are grateful to Professor D Catovsky (Royal Marsden NHS Trust Hospital, London, UK) for his suggestions and comments on the manuscript. This work was supported by the State Committee for Scientific Research (KBN, Poland, Grant no. 4 PO 5B 136 18).
Dustin ML, Cooper JA (2000) The immunological synapse and the action cytoskeleton: molecular hardware for T cell signaling. Nat Immunol 1: $23-29$

Ferguson SE, Han S, Kelsoe G, Thompson CB (1996) CD28 is required for germinal center formation. J Immunol 156: 4576-4581

Frydecka I, Kosmaczewska A, Bocko D, Wolowiec D, Kapelko-Slowik K, Urbaniak-Kujda D, Ciszak L, Kuliczkowski K, Kochanowska I (2003) IFN-gamma and IL - 2 production by peripheral blood mononuclear cells in patients with B-cell chronic lymphocytic leukemia. Adv Clin Exp Med 12: $565-568$

Gallego A, Vargas JA, Castejon R, Citores MJ, Romero Y, Millan I, Durantez A (2003) Production of intracellular IL-2, TNF-alpha, and IFN-gamma by T cells in B-CLL. Cytometry 56: $23-29$

Kosmaczewska A, Frydecka I, Bocko D, Ciszak L, Teodorowska R (2002) Correlation of blood lymphocyte CTLA-4 (CD152) induction in Hodgkin's disease with proliferative activity, interleukin 2 and interferon-gamma production. Br J Haematol 118: 202-209

Krummel MF, Allison JP (1996) CTLA-4 engagement inhibits IL-2 accumulation and cell cycle progression upon activation of resting $\mathrm{T}$ cells. J Exp Med 183: $2533-2540$

Labalette M, Leteurtre E, Thumerelle C, Grutzmacher C, Tourvieille B, Dessaint JP (1999) Peripheral human CD8+CD28+ T lymphocytes give rise to CD28- progeny, but IL-4 prevents loss of CD28 expression. Int Immunol 11: 1327-1335

Lee KM, Chuang E, Griffin M, Khattri R, Hong DK, Zhang W, Straus D, Samelson LE, Thompson CB, Bluestone JA (1998) Molecular basis of T cell inactivation by CTLA - 4. Science 282: 2263-2266

Lindsten T, Lee KP, Harris ES, Petryniak B, Craihead N, Reynolds PJ, Lombard DB, Freeman GJ, Nadler LM, Gray GS, Thompson CB, June CH (1993) Characterization of CTLA-4 structure and expression on human T cells. J Immunol 151: 3489-3499

Linsley P, Bradshaw J, Urnes M, Grosmaire L, Ledbetter J (1993) CD28 engagement by $\mathrm{B} 7 / \mathrm{BB} 1$ induces transient down-regulation of CD28 synthesis and prolonged unresponsiveness to CD28 signalling. $J$ Immunol 150: $3161-3169$ 
Linsley PS, Greene JL, Brady W, Bajorath J, Ledbetter JA, Peach R (1994) Human B.7-1 (CD80) and B.7-2 (CD86) bind with similar avidities but distinct kinetics to CD28 and CTLA-4 receptors. Immunity 1: 793-801

Metzler B, Burkhart C, Wraith DC (1999) Phenotypic analysis of CTLA-4 and CD28 expression during transient peptide-induced $\mathrm{T}$ cell activation in vivo. Int Immunol 11: $667-675$

Perussia B, Fanning V, Trinchieri G (1983) A human NK and K cell subset shares with cytotoxic $\mathrm{T}$ cells expression of the antigen recognized by antibody OKT8. J Immunol 131: 223-231

Rossi E, Matutes E, Morilla R, Owusu-Ankomah K, Heffernan AM, Catovsky D (1996) Zeta chain and CD28 are poorly expressed on T lymphocytes from chronic lymphocytic leukemia. Leukemia 10: 494-497

Schwartz RH (1996) Models of T cell anergy; is there a common molecular mechanism? J Exp Med 184: $1-8$

Scrivener S, Kaminski ER, Demaine A, Prentice A (2001) Analysis of the expression of critical activation/ interaction markers on peripheral blood $\mathrm{T}$ cells in B-cell chronic lymphocytic leukaemia: evidence of immune dysregulation. Br J Haematol 112: 959-964

Shahinian A, Pfeffer K, Lee KP, Kunding TM, Kishihara K, Wakeham A, Kawai K, Ohashi PS, Thompson CB, Mak TW (1993) Differential T cell costimulatory requirements in CD28-deficient mice. Science (Washington DC) 261: 609-612
Tivol EA, Boyd SD, McKeon S, Borriello F, Nickerson P, Strom TB, Sharpe AH (1997) CTLA-4 Ig prevents lymphoproliferation and fatal multiorgan tissue destruction in CTLA-4-deficient mice. J Immunol 158: $5091-5094$

Van den Hove LE, Vandenberghe P, Van Gool SW, Ceuppens JL, Demuynck H, Verhoef GE, Boogaerts MA (1998) Peripheral blood lymphocyte subsets in patients with untreated hematological tumors: evidence for systemic activation of the $\mathrm{T}$ cell compartment. Leukemia Res 22: $175-184$

Walunas TL, Bakker CY, Bluestone JA. (1996) CTLA-4 ligands blocks CD28-dependent T cell activation. J Exp Med 183: 2541 - 2550

Walunas TL, Lenshow DJ, Bakker CY, Linsley PS, Freeman GJ, Greene JM, Thompson CB, Bluestone JA (1994) CTLA-4 can function as a negative regulator of $\mathrm{T}$ cell activation. Immunity 1: $405-413$

Waterhouse P, Penninger JM, Timms E, Wakeham A, Shahinian A, Lee KP, Thompson CB, Griesser H, Mak TW (1995) Lymphoproliferative disorders with early lethality in mice deficient in CTLA-4. Science 270: 985- 988

Wolowiec D, Frydecka I, Kosmaczewska A, Bocko D, Ciszak L, UrbaniakKujda D, Kapelko-Slowik K, Kuliczkowski K, Kochanowska I (2003) Interleukin-4 and interleukin-10 secretion by peripheral blood $\mathrm{T}$ cells in patients with B-cell leukemia. Adv Clin Exp Med 12: 45-49 